\title{
A NEW RECORD OF A SOCIAL SPIDER, ANELOSIMUS LORENZO FOWLER AND LEVI, 1979 (ARANEAE, THERIDIIDAE), FROM A TEMPERATE ZONE (URUGUAY)
}

\author{
UN NUEVO REGISTRO DE UNA ARAÑA SOCIAL, ANELOSIMUS LORENZO \\ FOWLER Y LEVI, 1979 (ARANEAE, THERIDIIDAE), DE UNA ZONA \\ TEMPLADA (URUGUAY)
}

\author{
Carmen Viera ${ }^{1,2,3}$ \& Luis F. García ${ }^{1,2}$ \\ ${ }^{1}$ Departamento de Entomología, Facultad de Ciencias, Universidad de la República, Iguá 4225, 11400, Montevideo, \\ Uruguay. \\ ${ }^{2}$ Laboratorio Ecología del Comportamiento IIBCE. Av. Italia 3318, 11200, Montevideo, Uruguay. \\ ${ }^{3}$ E-mail: cviera@fcien.edu.uy
}

\section{RESUMEN}

Se registra Anelosimus lorenzo para Uruguay, constituyendo el hallazgo más austral de la especie. El presente registro confirma la inusual presencia de una araña social para una zona de clima templado. Con este nuevo reporte, el número de especies de Anelosimus conocidas para este país se eleva a tres.

The family Theridiidae is one of the most diverse spider groups with 2295 recognized species (Platnick 2009). Although not as diverse as other genera of this family, Anelosimus Simon, 1891 is relevant because it contains solitary, subsocial, and social species (Avilés 1997). Avilés (1997) suggests that sociality could have evolved several times within Anelosimus and as such, it has played a key role in order to understand the evolution of spider sociality. In a series of studies, Agnarsson (2004, 2005, 2006) and Agnarsson et al. (2006), have clarified different systematic aspects of this group; nevertheless, the species of this genus still remains partially unknown, e.g., the taxonomic identity of the Uruguayan subsocial form referred as to $A$. cf studiosus.

In Uruguay there are records of two subsocial spiders: Anelosimus ethicus Keyserling, 1884 (Benamú-Pino unpublished data) and $A$. cf. studiosus (Agnarsson, pers. com.). The behavior of the latter has been intensively studied (Viera \& Albo 2008; Ghione et al. 2004; Albo et al. 2007; Viera et al. 2006, 2007a, 2007b, 2007c).
In this paper we report the first Uruguayan record of the species A. lorenzo Fowler \& Levi, 1979. Studied specimens were deposited in Colección Entomológica de la Facultad de Ciencias (FCEN Ar-2471).

Nests from two sites were collected: 1) Estación Experimental "Las Brujas" of INIA (Instituto Nacional de Investigación Agraria), Canelones (34 ${ }^{\circ}$ $\left.39^{\prime} \mathrm{S} ; 56^{\circ} 21^{\prime} \mathrm{W}\right)$. This nest was found associated to Acacia caven Molina, 1810 (Fabales: Fabaceae), and had 180 individuals (Fig. 1). Acacia caven presents spines that could provide protection to the spiders. 2) Playa la Agraciada, Soriano (33 ${ }^{\circ}$ $\left.48^{\prime} \mathrm{S} ; 58^{\circ} 25^{\prime} \mathrm{W}\right)$. This nest was found associated to Schinus lentiscifolius Marchand, 1869 and had 152 individuals. In both nests spiders were mostly juveniles. Therefore, to identify the species and to know the secondary sex ratio, juveniles were raised under lab conditions (average temperature $17 \pm 3^{\circ} \mathrm{C}$, humidity $70 \%$ ) maintaining original colonies composition, during four months. Sex ratio was extremely biased toward females: 10 males and 170 females in the first nest and 13 males 
Gayana 73(2), 2009

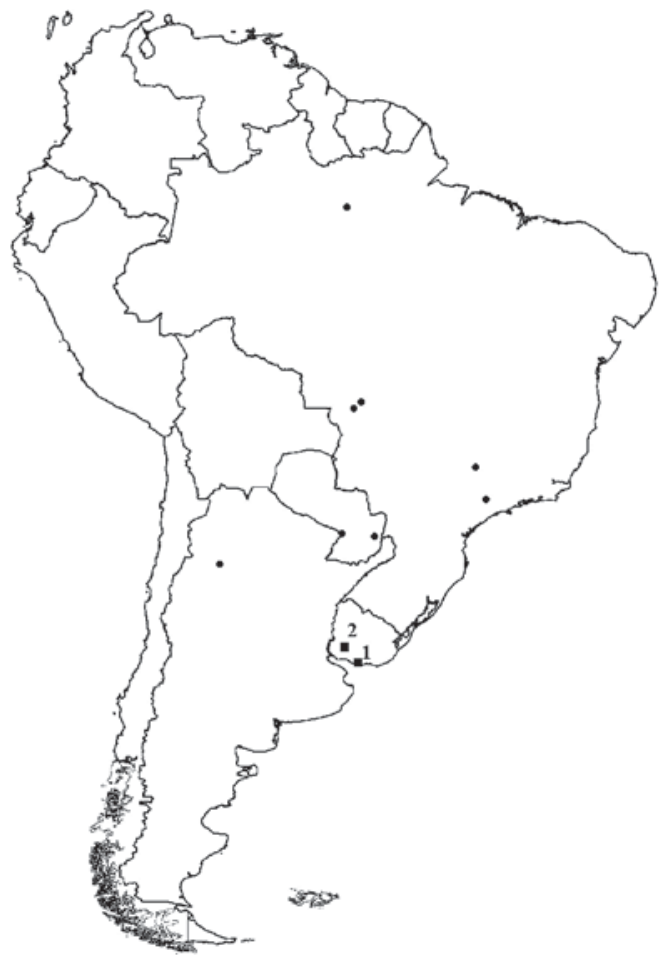

Figure 1. Records for Anelosimus lorenzo. Circles indicate previous records according to Agnarsson (2006), squares indicate new records from Uruguay: 1) INIA "Las Brujas", Canelones; 2) Playa la Agraciada, Soriano.

Figura 1. Registros de Anelosimus lorenzo. Los círculos indican los registros anteriores según Agnarsson (2006), los cuadrados indican los nuevos registros de Uruguay: 1) INIA "Las Brujas”, Canelones; 2) Playa la Agraciada, Soriano.

and 136 females in the second one. This biased sex ratio is typical of social spiders like Anelosimus eximius (Keyserling, 1884) (Buskirk 1981). The specimens were fed ad libitum with Drosophila sp. flies, even when most of food items found in the nest were carcasses of beetles (Coleoptera: Bruchidae, Chrysomelidae, Coccinelidae, Curculionidae), bees (Apis mellifera), wasps (Hymenoptera: Vespidae), ants (Hymenoptera: Formicidae), leafhoppers (Hemiptera: Cicadellidae), and flies (Diptera: Calliphoridae). In the case of A. lorenzo, additional observations performed by Fowler \& Levi (1979), suggest that this species like other social spiders can build nests of almost 1.4 $\mathrm{m}^{3}$, with 550 individuals. It is possible that Uruguayan climatic conditions prevent the species reaching those large numbers.

A. lorenzo and A. rupununi Levi, 1956 form the rupununi group (Agnarsson, 2006). Although both species are very similar, the former can be distinguished from the later by the presence of a thicker basal portion of male embolus, by the extended base of the embolus directed towards the palpal tibia (Fig. 3a) and by a more rounded female epyginum (Figs.3b, 3c ). In addition, adults of $A$. lorenzo are considerably larger than adults of A. rupununi (Agnarsson 2006). All characters mentioned above, were found on our specimens. However, the dark spot pattern on leg I was not observed (Fig. 3d) this character is not present in all populations of A. lorenzo and would not be widespread among the group.

The presence of this social spider in Uruguay is an unusual finding, because most of social species live on tropical countries, while Uruguay presents a temperate and markedly seasonal weather (max. temp: $21.0^{\circ} \mathrm{C}$, min. temp: $11.7^{\circ} \mathrm{C}$, average precipitation: $1136 \mathrm{~mm}$ per year) compared to places where this species had been previously recorded: i.e. Manaus, Brazil (max temp: $31.9^{\circ} \mathrm{C}$, min temp: $24.9^{\circ} \mathrm{C}$, average precipitation: $2300 \mathrm{~mm}$ per year); 


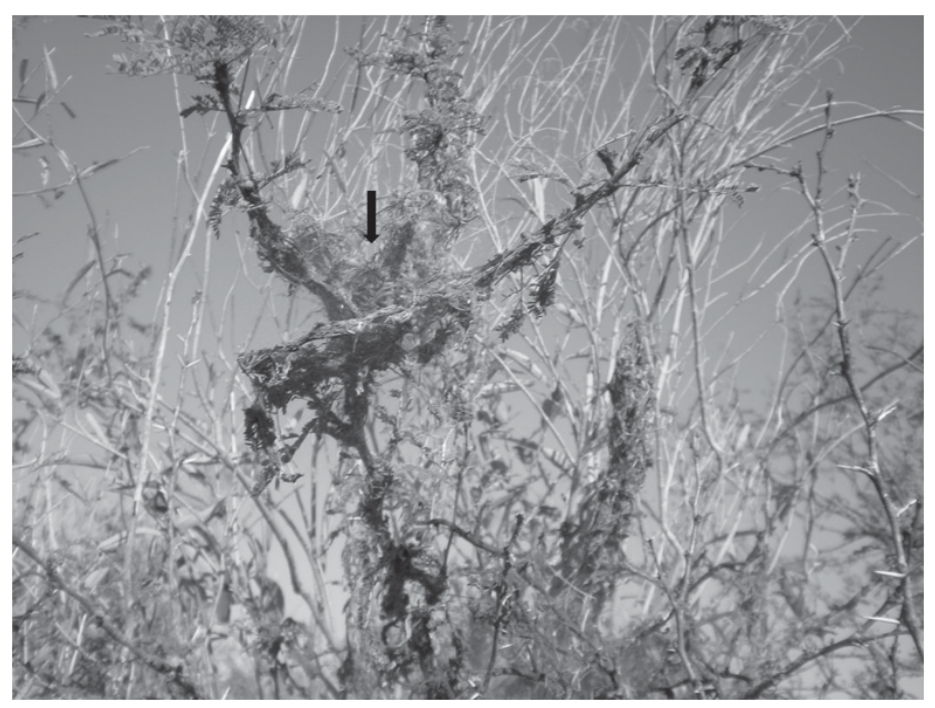

Figure 2. Nest of Anelosimus lorenzo on Acacia caven. Arrow indicates the nest.

Figura 2. Nido de Anelosimus lorenzo sobre Acacia caven. La flecha indica el nido.

San Lorenzo, Paraguay (max temp: $28.9^{\circ} \mathrm{C}$, min temp: $17.4^{\circ} \mathrm{C}$, average precipitation: $1600 \mathrm{~mm}$ per year); Catamarca, Argentina (max temp: $26.3^{\circ} \mathrm{C}$, min temp: $10.9^{\circ} \mathrm{C}$, average precipitation: $307 \mathrm{~mm}$ per year) (Hijmans et al. 2004). According to Buskirk (1981), Riechert \& Jones (2008), Jones et al. (2007), Witehouse \& Lubin (2007), and Powers \& Avilés (2007) the continuous flow of food availability represents the critical factor that would limit the distribution of social spiders to tropical zones. In addition, lack of a supply of sufficient large preys may be a determinant factor to avoid the presence of social spiders in temperate zones like Uruguay. In fact, social spiders are unknown in countries with temperate weather according to the list elaborated by Olivera-Gonzaga (in lit). The new record we provide on this paper is the most austral for this species, which had been recorded previously for Argentina, Brazil and Paraguay (Agnarsson, 2006) being $7^{\circ} 4^{\prime}$ southern than the last record. Finally, this new record, together with those two of Laborda \& Simó (2008), indicates that much remains to be learnt about basic aspects of the Uruguayan spider assemblage.

\section{ACKNOWLEDGMENTS}

We thank Miguel Simó and Alvaro Laborda for the
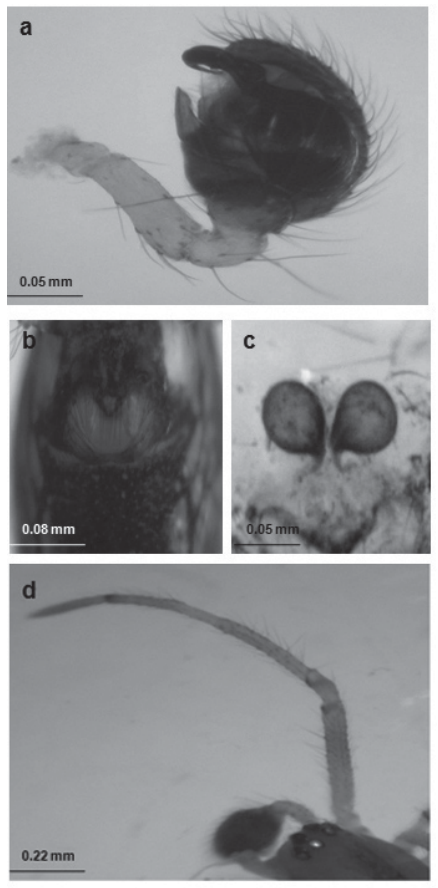

Figure 3. Anelosimus lorenzo: a) ventral view of the palp; b) epyginum; c) internal epyginum and d) lateral view of leg I of male.

Figura 3. Anelosimus lorenzo: a) vista ventral del palpo; b) epigino; c) epigino interno y d) vista lateral de la pata I del macho. 
Gayana 73(2), 2009

confirmation of the species identification, Patricia González for the insect determinations, and to the anonymous referees for their comments.

\section{BIBLIOGRAPHY}

Agnarsson, I. 2004. Morphological phylogeny of cobweb spiders and their relatives (Araneae, Araneoidea, Theridiidae). Zoological Journal of Linnean Society 141(4):447-626.

Agnarsson, I. 2005. A revision and phylogenetic analysis of the American ethicus and rupununi groups of Anelosimus (Araneae, Theridiidae). Zoologica Scripta 34(4):389-413.

Agnarsson, I. 2006. A revision of the New World eximius group of Anelosimus (Araneae, Theridiidae) and a phylogenetic analysis using worldwide exemplars. Zoological Journal of Linnean Society 146 (4):453-593.

Agnarsson, I., Maddisson, W. P. \& Avilés, L. 2007. The phylogeny of the social Anelosimus spiders (Araneae: Theridiidae) inferred from six molecular loci and morphology. Molecular Phylogenetics and Evolution 43(3):833-851.

Albo, M.J., Viera, C. \& Costa, F.G. 2007. Pseudocopulation and male-male conflict elicited by subadult females of the subsocial spider Anelosimus cf. studiosus (Theridiidae). Behaviour 144(10):12171234.

AvILÉs, L. 1997. Causes and consequences of cooperation and permanent-sociality in spiders. In: The Evolution of Social Insects and Arachnids (Eds. Choe, J.C. \& B.J. Crespi), pp. 476-498. Cambridge University Press, Cambridge.

Benamú-Pino, M. A. 2004. Estudio comparativo de la diversidad de arañas de un campo en abandono y un cultivo convencional de limonero Citrus limon en Rincón del Cerro, Uruguay. Tesis de Magíster. Universidad de la República, Montevideo, Uruguay.

BuskiRK, R. 1981. Sociality in the Arachnida. In: Social insects. H. R. Hermann Ed. Academic Press. 281- 367.

Fowler, H. G. \& LeVI, H.W. 1979. A new quasisocial Anelosimus spider from Paraguay. Psyche 86(1):11-18.

Ghione, S., Viera, C. \& Costa, F.G. 2004. Ability for prey capture in the early instars of the subsocial spider Anelosimus studiosus (Hentz, 1850) from Uruguay (Araneae, Theridiidae). Bulletin of the
British Arachnological Society 3(2) 60-62.

Hijmans, R.J., Guarino, L., Bussink, C., Mathur, P., Cruz, M., Barrentes, I. 2004. DIVA-GIS. Vsn. 5.0. A geographic information system for the analysis of species distribution data. (http://www. diva-gis.org).

Jones,T.C., Riechert, S.E., Dalrymple, S.E. \& Parker, P.G. 2007. Fostering model explains environmental variation in levels of sociality in a spider system. Animal Behaviour 73 (1): 195-204.

Laborda, A. \& Simó, M. 2008. First South American records of Holocnemus pluchei (Scopoli, 1763) and Spermophora senoculata (Dugés, 1836) (Araneae: Pholcidae). Gayana 72 (2):261-265.

Platnick, N. I. 2009. The world spider catalog, version 10.0 American Museum of Natural History. URL: http://research.amnh.org/entomology/spiders/ catalog/index.html. Accesado: August 10, 2009.

Powers, K.S. \& AviLÉs, L. 2007. The role of prey size and abundance in the geographical distribution of spider sociality. Journal of Animal Ecology 76(5):995-1003.

Riechert, S.E. \& Jones, T.C. 2007. Phenotypic variation in the social behavior of the spider Anelosimus studiosus along a latitudinal gradient. Animal Behaviour 75(6): 1893-1902.

Viera, C. \& Albo, M. J. 2008. Males of a subsocial spider choose among females of different age and same reproductive status. Ethology, Ecology and Evolution 20(1):35-41.

Viera C., Ghione, S. \& Costa, F.G. 2006. Regurgitation among juveniles in the subsocial spider Anelosimus studiosus (Araneae, Theridiidae). Journal of Arachnology 34 (1):258-260.

Viera, C., Costa, F.G., Ghione, S. \& Benamú-Pino, M.A. 2007a. Progeny, development and phenology of the sub-social spider Anelosimus cf. studiosus (Araneae, Theridiidae) from Uruguay. Studies on Neotropical Fauna and Environment 42(2):145-153.

Viera, C., Ghione, S. \& Costa, F. G. 2007b. Postembryonic development of the sub-social spider Anelosimus cf. studiosus (Araneae, Theridiidae). Bulletin of the British arachnological Society 14(1):30-32.

Viera, C., Ghione, S. \& Costa, F.G. 2007c. Mechanisms underlying egg-sac opening in the subsocial spider Anelosimus cf. studiosus (Araneae, Theridiidae. Ethology Ecology \& Evolution 19 (1):61-67.

Whitehouse, M.E.A. \& Lubin, Y. 2005. The functions of societies and the evolution of group living: Spider societies as a test case. Biological Reviews 80 (1):1-15. 